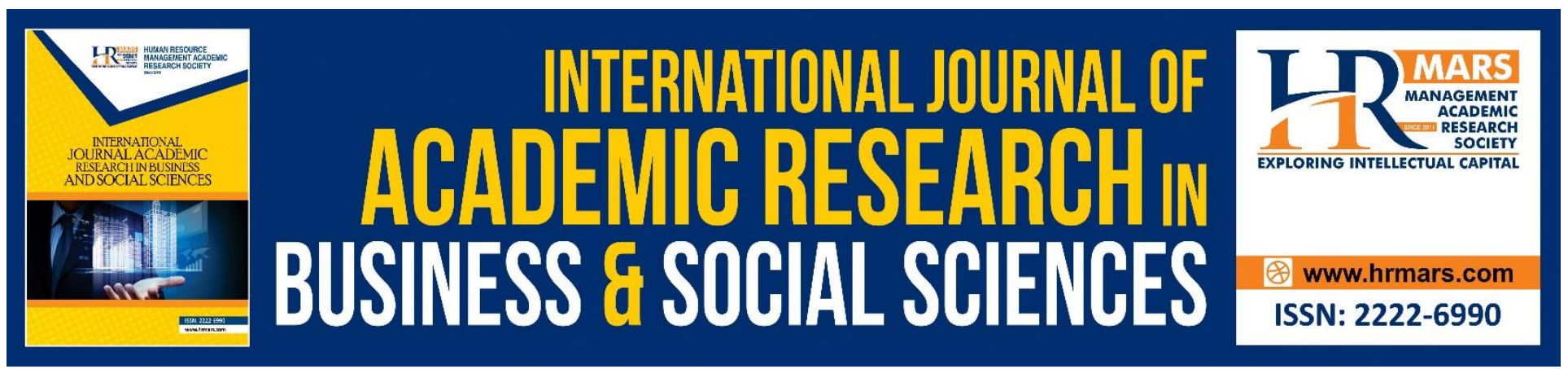

\title{
Strategies of Postgraduate Students in Completing Studies: A Qualitative Analysis
}

Abdul Munir Ismail, Zulkifli Osman and Muhammad Akramin

To Link this Article: http://dx.doi.org/10.6007/IJARBSS/v10-i9/7743 $\quad$ DOI:10.6007/IJARBSS/v10-i9/7743

Received: 04 June 2020, Revised: 09 July 2020, Accepted: 15 August 2020

Published Online: 20 September 2020

In-Text Citation: (Ismail, Osman, and Akramin, 2020)

To Cite this Article: Ismail, A. M., Osman, Z., and Akramin, M. (2020). Strategies of Postgraduate Students in Completing Studies: A Qualitative Analysis. International Journal of Academic Research in Business and Social Sciences. 10(9), 300-308.

Copyright: (C) 2020 The Author(s)

Published by Human Resource Management Academic Research Society (www.hrmars.com)

This article is published under the Creative Commons Attribution (CC BY 4.0) license. Anyone may reproduce, distribute, translate and create derivative works of this article (for both commercial and non-commercial purposes), subject to full attribution to the original publication and authors. The full terms of this license may be seen

at: http://creativecommons.org/licences/by/4.0/legalcode

Vol. 10, No. 9, 2020, Pg. 300 - 308

http://hrmars.com/index.php/pages/detail/IJARBSS

JOURNAL HOMEPAGE

Full Terms \& Conditions of access and use can be found at http://hrmars.com/index.php/pages/detail/publication-ethics 


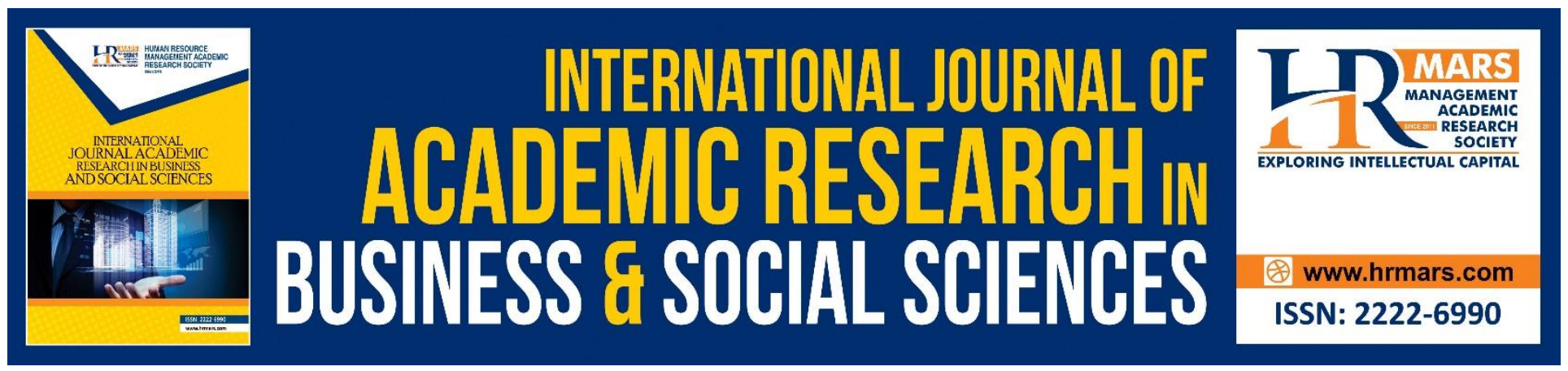

\title{
Strategies of Postgraduate Students in Completing Studies: A Qualitative Analysis
}

\author{
Abdul Munir Ismail, Zulkifli Osman and Muhammad Akramin \\ Faculty of Human Sciences, Sultan Idris Education University, Malaysia \\ Email: abdmunir@fsk.upsi.edu.my
}

\begin{abstract}
This study examines the strategies of postgraduate students in completing their studies at the stipulated time by the university. There are a number of students who are unable to complete their studies and are at risk of being expelled from university. This study uses qualitative methods. Interviews are the main elements to obtain data and information of respondents. Respondents consisted of five postgraduate students. Qualitative interview data were collected and analyzed descriptively. The results of the study found that students' strategies are meeting the supervisors frequently, students are very committed to thesis writing and parents often provide moral support to students is an effective strategy. In addition, students with sufficient money are an important strategy for postgraduate students to complete their studies within the period set by the university. The results of this study are beneficial to thesis supervisors, lecturers and university support staff to provide moral support for students to graduate within the stipulated period.
\end{abstract}

Keywords: Strategies, Postgraduate, Completing Studies.

\section{Introduction}

Based on the Graduate Tracking Study Report 2018, the number of undergraduate students pursuing master's level studies is $67.5 \%$, whereas only $81.5 \%$ of master's students who continue their PhD studies (Ministry of Education Malaysia, 2019). This statement also refers to the Admission Statistics of Master's and PhD Students, Department of Higher Education 2018, Ministry of Education Malaysia as in Table 1.

Table 1: Number of Master's and PhD Students in Malaysia

\begin{tabular}{cccccc}
\hline No. & Study & Category of IPT & Admission & Enrolment & $\begin{array}{c}\text { Total of } \\
\text { Graduates }\end{array}$ \\
\hline 1. & PhD & IPTA & 6,855 & 35,362 & 4,121 \\
& & IPTS & 1,622 & 7,817 & 660 \\
2. & \multirow{2}{*}{ Master } & IPTA & 20,081 & 58,240 & 15,193 \\
& & IPTS & 8,094 & 31,574 & 5,439 \\
\hline
\end{tabular}

Source: Planning and Policy Coordination Department, KPM 2019 
To finance their studies, scholarships and financial loans are provided by financial institutions to interested and qualified students. This is in line with the Malaysian Government's aspiration to make this country a developed country, on par with other developed countries that prioritize higher education, (Ministry of Higher Education Malaysia, 2018). As known to the public, the people's investment in higher education is the main drive to help Malaysia achieve a developed country in education.

The Covid-19 pandemic changes which strike the world demanding the postgraduate students to change their minds in completing a master's or PhD degree that is not complicated. In order to achieve this aim, students should take two to five years and they need effective techniques and strategies to complete the thesis.

Based on the Malaysian Qualifications Agency (2015), the number of words for the Master's thesis is 150 words and PhD is 250 words. According to the Malaysian Qualifications Agency (2015), master's and $\mathrm{PhD}$ candidates need to develop the knowledge to the community. Such knowledge covers the fields of social science, pure science and various disciplines. The basis of knowledge of graduate students is that they are capable of doing research, capable of delivering effective communication and able to publish scholarly writing through the writing of indexed or Scopus journals. Thus, according to Simon and Goes (2013), they need to work hard effort to achieve these three components, namely self-confidence to defend the results of their studies, able to do research well and publish high-impact journal writing successfully. In addition, Helmi (2015) explained that postgraduate students should have attractive professionalism values, noble character, have a sense of identity, high leadership talent in professionalism and master the writing well.

The objective of this study is to:

1. Reveal postgraduate student strategies from the aspect of face to face with supervisor and student commitment.

2. To know the aspects of moral support and financial factors as an important element of graduate students to complete their studies.

\section{Study Problem}

According to Munir A. \& Muhamad, N. (2019), there are postgraduate students who cannot complete their studies and they need to add a semester to complete their studies. Among the reasons are the difficulty of adjusting time with supervisors, students are not serious in writing theses and financial problems. Meanwhile, Julita (2015) says there are postgraduate students who fail in completing their studies within the stipulated period. The reason are that there is no thesis guidance schedule, students are not in good terms with supervisors, financial problems, lack of moral support and students are inconsistent in writing. According to Aladdin and Ahmad (2017) in the financial aspect, there are many postgraduate students who are working in various sectors as a source of income to continue their studies.

\section{Methodology}

Researchers use a structured qualitative approach aimed at obtaining detailed and effective research results. The study sample was selected from Master's students and PhD students. This study uses a 
semi-structured interview approach on selected respondents. The interview instrument was built based on the study objectives (Mohajan, 2018). Student selection criteria must be students in semester two and above, social sciences students, students are working on their thesis and have not yet completed their study. Interview time ranges from 10 minutes to 20 minutes. The interview process is done in a closed, appropriate and comfortable location such as a meeting room. Questions were asked spontaneously and structurally to the respondents. The researcher assured the respondents that this study is a scientific study. Therefore, respondents are free to express their views without prejudice. Researchers carried out the voice recordings using a smartphone with the consent of the respondents. Personal information such as full name, marital status, age and field of study are also recorded for a thorough analysis, combined data analysis methods, library research and field research (Wolf \& Phung, 2019). Respondents' names are written as R1 to R5 to protect their interests.

\section{Results and Discussion}

The following are the study findings which are categorized into four main strategies for postgraduate students to complete their studies.

\section{Meeting the Supervisor}

According to Darmono (2002), face-to-face learning strategies with the thesis supervisor for the determination of the thesis title is very important to decide whether the topic is relevant or not. Faceto-face meetings continue for many planned or unplanned series and preferably bilateral discussions are conducted in harmonious situations. The benefit of face-to-face strategies is that the students are not easily bored because the function of the supervisor who acts as a facilitator so that students will fully understand thesis writing. According to Salleh and Abdul Manaf (2017), supervisors give suggestions to postgraduate students on the methods of testing theories and appropriate research concepts. Supervisors also must ensure that the titles are still relevant in the past studies. If the objectives of the study are very broad, then the candidate needs to limit the study so that the scope of the discussion is more focused and answers the study objectives. Candidates are unlikely to be able to fulfill an objective if the scope of the study cannot be measured using appropriate parameters.

Based on the R1 interview, a Master of Education student from Universiti Teknologi Malaysia (UTM), a Social Sciences and Humanities student in semester three and specialized in Management and Administration. Regarding the strategy on completing the studies, R1 explained as follows:

For me, students should often meet the supervising lecturer. Supervisors, on the other hand, should always ask the progress of the thesis writing.

Based on the interview, R2 is a sixth semester PhD student, Shariah (Figh), School of Humanities, Universiti Sains Malaysia (USM). Regarding the meeting with the supervisor to complete the study, R2 explained as follows:

Students must face the supervisor in any situation to guide students on how to write quality theses and journals, in accordance with the writing theme and methods of improving the evaluator's comments (R2). 
INTERNATIONAL JOURNAL OF ACADEMIC RESEARCH IN BUSINESS AND SOCIAL SCIENCES Vol. 10, No. 9, 2020, E-ISSN: 2222-6990 @ 2020 HRMARS

Based on R1 and R2 interviews, they agreed to discuss with the supervisor regarding the method of selection of thesis title because the supervisor is more experienced in the selection of thesis title. The process of meeting between the students with the supervisors should be mutual respect, focused topic guidance and a high sense of responsibility between teachers and students. According to Azmi (2010), in certain circumstances, students need to comply with the views of the supervisors even if the students do not agree. This is the sign of respect to the supervisor who is given the responsibility of supervising the thesis. Face-to-face meetings with supervisors are intended for quality thesis guidance. Thus, graduate students will gain many benefits based on this view so that they can complete their studies within the stipulated period.

\section{Commitment Towards Study}

Syed Mohamed et al. (2020) explains that the higher education requires candidates who have the desire to seek high knowledge. They must also have a strong commitment and identity. This is because students have to overcome various obstacles in the future. Among the examples, namely lack of enthusiasm in themselves such as the students failing to get the necessary reference materials causing unstable emotions, lack of self-motivation, thesis writing problems and problems with the supervisors.

Respondent R3, a second semester Master's student in Natural Disaster Management Study (UUM). Full-time students are financially sponsored by a leading financial institution. When asked about commitment in learning, R3 explained:

Humans often experience symptoms of lazy learning, let alone long periods of time.

For that, I try to release tension by attending the seminar and asking for the supervisor's opinion on what needs to be done.

According to Hamsar and Kechot (2017), the students' spirits also fade due to the bureaucracy while in the process of obtaining research data. Meanwhile, Karkar-Esperat (2018) says that graduate students have to struggle to obtain a degree and to achieve it requires a lot of sacrifices. They need to work hard to get that knowledge. In order to meet the challenge, postgraduate students need to instill in their minds that the pursuit of master's and PhD knowledge in their respective specialties is a demand in religion. Postgraduate students should determine to excel in academic achievement. Therefore, they can get hired that suits their qualifications. Thus, they can improve the economic status of their lives in the future.

According to He and Hutson (2018), students who want to succeed in postgraduate studies should be willing to receive constructive criticism from supervisors, friends and other lecturers. Cassuto (2013) explains that thesis writing requires a distinctive style of language and art. Researchers are convinced that many students are not ready to accept their own shortcomings due to excessive egoistic nature. It is possible that the educational background of the respondents who less sociable well in society causes them to be alone even though they are already in higher education. They were embarrassed to ask the senior about the thesis writing. Thompson (2018) explains it is including the ego that the students find it difficult to get rid of shyness to ask people who are more knowledgeable. That is a sign of one of the traits of the arrogant person. If this attitude is not eliminated, it is detrimental to the student himself. 
INTERNATIONAL JOURNAL OF ACADEMIC RESEARCH IN BUSINESS AND SOCIAL SCIENCES Vol. 10, No. 9, 2020, E-ISSN: 2222-6990 @ 2020 HRMARS

\section{Moral Support}

Referring to the School of Graduate Studies (2018) guide, moral support means students get indirect support from supervisors, friends, parents for the purpose of completing their studies. Postgraduate students need moral support from supervisors, university staff and immediate family members to encourage them to complete their studies immediately.

Based on the R4 interview, a seventh semester PhD student in Law and Shariah, Universiti Sains Islam Malaysia (USIM). When asked about the strategy of completing studies from the aspect of moral support, R4 explained:

Although students are grown-ups, but moral support, especially supervisors, immediate family members and friends is very important to give encouragement and moral support so that we can complete our studies faster.

Based on the findings of the R4 interview, postgraduate students expressed concern that they could not finish their studies on time due to many obstacles faced by students. According to Julita (2015), among the obstacles faced by postgraduate students is because of the supervisors' attitude, bureaucracy of university staff, live apart from family members, parents, husbands, wives as well as children. As they struggle with the academic burden and thesis research, moral and mental support from the community is essential as an effective strategy for completing studies.

Researchers viewed that the supervisors should stimulate students' minds so that they are able to complete their studies within a minimum period of time. To achieve this, supervisors must help students such as helping to formulate the study concept, review the survey form, preparation of thesis viva, journal writing and others. Students feel a satisfaction to be able to discuss their thesis writing with the supervisor. A supervisor must also monitors the students' daily developments or activities. If the students are facing problems obtaining research resources, supervisors must be willing to provide assistance such as suggesting suitable locations to obtain research resources.

\section{Financial Factor}

According to Seman and Ahmad (2017), the students should have sufficient financial resources for various expenses while studying at university. Money is needed for the purchase of books, payment of semester fees, meals and daily transportation costs. For students with sufficient financial resources, it may not be an obstacle. Aladdin and Ahmad (2017) said that the students who do not have enough financial resources are a barrier to finish their studies at university.

Based on R5 interview, a fifth semester Master's student, Faculty of Language and Communication (UPSI). When asked about the financial factors of graduate students completing their studies, R5 explained:

I really need money to buy a quality laptop. This is to facilitate online classes including using teleconferencing applications.

According to Abdul Rahman and Zulkifly (2016), students are encouraged to do side jobs such as sales assistant, oil pump assistant, internet-based online business, part-time tuition instructor and other jobs according to one's capability. Akmal and Azman (2013) suggested that postgraduate students to 
INTERNATIONAL JOURNAL OF ACADEMIC RESEARCH IN BUSINESS AND SOCIAL SCIENCES Vol. 10, No. 9, 2020, E-ISSN: 2222-6990 @ 2020 HRMARS

organize their daily schedule practically. This is important to ensure a balanced amount of work and study time and allows them to complete their studies immediately. According to Nordin and Singh (2018), working while studying is necessary for postgraduate students to obtain financial resources. It is now proven that many graduate students can complete their studies because they have enough money to graduate from the university.

\section{Conclusion and Recommendations}

Based on the above discussion, the researchers concluded that the method of meeting the supervisor once a week frequently is very practical. The duration of the thesis supervision must not exceed one hour per meeting. Postgraduate students who are unable to complete their studies within the stipulated period contribute some implications such as increased financial burden where they have to pay semester fees, house rent, food, transportation and others. If the student has a problem with the supervisor, the researcher recommends replacing the supervisor who understands the student's problem, helping each other and complementing each other. Supervisors are also having a huge responsibility graduating their students. Therefore, moral support is very important to postgraduate students in order to complete their studies immediately. The results of this study are beneficial to thesis supervisors, lecturers and university support staff in producing graduates who can finish their studies within the stipulated period (graduate on time).

This research aims to provide special contributions to all and prospective students and postgraduate students who will graduate. Based on the theory and conceptualization of the study, students 'strategies face to face with supervisors, students give high commitment in thesis writing, moral support from the university as well as students' family members are seen to greatly influence this writing concept. Similarly, the financial aspect of students contributes to the important strategies of students completing their studies because, without adequate finances, students fail to complete their studies.

\section{Acknowledgement}

I would like to thank Sultan Idris Education University for funding this research - Grant No: 20170313-107-01.

\section{References}

Abdul Rahman, A., \& Zulkifly, W. (2016). Determinants of financial management: The case of Universiti Kebangsaan Malaysia Students. Jurnal Personalia Pelajar, 19 (2), 85-94.

Akmal, H., \& Azman, N. (2013). Perkaitan antara pengurusan masa dan stres dalam kalangan pelajar siswazah di IPTA. Jurnal AJTLHE, 5(1), 50-60.

Aladdin, Y. H., \& Ahmad, A. (2017). Tahap literasi kewangan di kalangan mahasiswa. Prosiding dalam seminar International Conference on Global Education V Global Education, Common Wealth, and Cultural Diversity, UKM.

Azmi, K. (2010). Guru cemerlang Pendidikan Islam sekolah menengah di Malaysia: Satu kajian kes. Tesis Doktor Falsafah. Fakulti Pendidikan, Universiti Kebangsaan Malaysia, Bangi.

Cassuto, I. (2013). Ph.d. Attrition: how much is too much? The chronicle of higher education. Last retrieved (3 july 2014) http://chronicle.com/article/phd-attrition-how-much-is/140045/

Darmono. (2002). Completing thesis in one semester. Bandung: Grasindo. 
INTERNATIONAL JOURNAL OF ACADEMIC RESEARCH IN BUSINESS AND SOCIAL SCIENCES Vol. 10, No. 9, 2020, E-ISSN: 2222-6990 @ 2020 HRMARS

Hamsar, S. R., \& Kechot, A. S. (2017). Bureaucracy in Arts Organization: A case study of Kuala Lumpur City Hall Music Unit. Jurnal Melayu, 16 (2) , 147 -162.

He, Y., \& Hutson, B. (2018). Exploring and leveraging Chinese international students' strengths for success. Journal of International Students, 8(1), 87-108.

Helmi, J. (2015). Teacher professional competence. AL-ISHLAH: Jurnal Pendidikan, 7 (2), 32-40.

Julita. (2015). Observation factors in completion of thesis students in the Department of Family Welfare. Unpublish Master Thesis, Faculty of Engineering, Padang State University, Indonesia.

Kaskar-Esperat, T. M. (2018). International Graduate Students' challenges and learning experiences in online classes. Journal of International Students, 8 (4), 1722-1735.

Malaysian Qualifications Agency. (2015). Standard: Ijazah Sarjana dan Kedoktoran. Petaling Jaya: Bahagian Standard Agensi Kelayakan Malaysia (MQA).

Ministry of Education Malaysia. (2015). Pelan Pembangunan Pendidikan Malaysia (Pendidikan Tinggi) 2015 - 2025. Putrajaya: Kementerian Pengajian Tinggi Malaysia.

Ministry of Education Malaysia. (2019). Laporan Kajian Pengesanan Graduan 2018. Putrajaya: Bahagian Perancangan dan Penyelarasan Dasar, Kementerian Pendidikan Malaysia.

Ministry of Higher Education Malaysia. (2018). Pembelajaran Sepanjang Hayat Peringkat Nasional $2017 / 2018$.

Mohajan, H. K. (2018). Qualitative research methodology in social sciences and related subjects. Journal of Economic Development, Environment and People. 1 (2), 10-18.

Munir, A., \& Muhamad, N. (2019). Cabaran pembelajaran pelajar lepasan ijazah Pengajian Islam di Malaysia. Jurnal Islam Dan Masyarakat Kontemporari, 20 (2), 1-15.

Nordin, H., \& Singh, D. (2018). e-learning in institute of higher education from the perspective of generation $\mathrm{y}$ and culture. Asean Journal of Teaching and Learning in Higher Education (AJTLHE), 8(2), 16-34.

Salleh, H., \& Abdul Manaf, M. (2017). Pengintegrasian pembelajaran teradun dalam pembelajaran berasaskan kerja (Work Based Learning). Jurnal Kejuruteraan, Teknologi dan Sains Sosial, 1(1) (Special Issue - NaCoSC'17).

School of Graduate Studies. (2018). Police And Code Of Practice Learning And Pasca Education Students. Skudai: Post-Graduate Learning and Teaching Policies, Universiti Teknologi Malaysia.

Seman, A. P. \& Ahmad, A. (2017). Pola perbelanjaan dalam kalangan mahasiswa: Satu kajian perbandingan antara IPTA Dan IPTS. International Conference on Global Education. 4 (2), 120.

Simon, M., \& Goes, J. (2013). Scope, limitations and delimitations, includes excerpt from Simon \& Goes, Dissertations and Scholarly Research: Recipes for Success Seattle, WA: Dissertation Success, LLC.

Mohamed, S. A. T. F., Amir, A. F., Ab. Rahman, N. K., Abd Rahman, E., \& Abdul Nasir, A. Q. (2020) Preparing for PhD: Exploring doctoral students' preparation strategy. (2020). International Journal for Researcher Development. 11(1), pp. 89-106. https:// doi.org/ 10.1108/ SGPE-032019-0038.

Thompson, C. (2018). The soul of shame: Retelling the stories we believe about ourselves. Downers Grove, IL: InterVarsity Press. 
INTERNATIONAL JOURNAL OF ACADEMIC RESEARCH IN BUSINESS AND SOCIAL SCIENCES Vol. 10, No. 9, 2020, E-ISSN: 2222-6990 @ 2020 HRMARS

Wolf, D. M., \& Phung, L. (2019). Studying in the United States: Language learning challenges, strategies and support services. Journal of International Students, 9(1), 211-224. https://doi.org/10.32674/jis.v9i1. 273. 